\title{
Population status, breeding biology and conservation of the Tristan Albatross Diomedea [exulans] dabbenena
}

\author{
PETER G. RYAN, JOHN COOPER and JAMES P. GLASS
}

\section{Summary}

Tristan Albatross Diomedea [exulans] dabbenena is the most genetically distinct of the five taxa that form the Wandering Albatross superspecies, and has been listed as Endangered. It breeds only on Gough and Inaccessible Islands in the Tristan da Cunha group, central South Atlantic Ocean. The entire breeding population was surveyed during 1999-2000. A mid-September survey at Gough Island recorded 1,129 chicks, equivalent to an annual breeding effort by approximately 1,500 pairs. Only one chick was present at Inaccessible Island in 1999, and another pair laid an egg in 2000. The annual breeding effort at this island has not exceeded three pairs since the 1950s. None were found during an incomplete survey at Tristan, where the species bred in the past, but birds were seen flying over the island. A complete survey and attempts to promote recolonization of Tristan are warranted. Breeding success at Gough Island averaged 63\%, and no birds that bred successfully attempted to breed the following year. Breeding success was greater and less variable in a large colony at Gonydale than at a peripheral colony at Tafelkop. Young birds returned to the island after 3-4 years (4-5 years old), and the modal age of first breeding was 8 years, with some individuals breeding as young as 6 years. Most chicks $(81 \%)$ recruited to their natal colony, but some recruited to colonies up to $3 \mathrm{~km}$ from their natal site. Among adults, fidelity to partners and breeding colony was high. Of nine birds recovered away from the island, at least four were killed by longline fishing. Despite its known mortality on longlines, the Gough Island census exceeded demipopulation estimates from the 1970 and early 1980s, possibly due to incomplete coverage by previous surveys and a poor breeding season in 1998. Given the lack of evidence for a population decrease, Tristan Albatross should be listed as Vulnerable. It is the third rarest albatross species, however, and its population size warrants monitoring. We provide guidelines for repeatable censuses at Gough Island.

\section{Introduction}

Recent genetic and morphological studies have resulted in the splitting of numerous albatross species (Robertson and Nunn 1998). Although more evidence should be published to support some of the proposed splits (e.g. Bourne and Warham 1999), the new taxonomy has been broadly accepted (e.g. Gales 1998, Croxall and Gales 1998). The resulting smaller population sizes and more restricted ranges, in conjunction with population decreases linked to the accidental by-catch of albatrosses by longline fisheries, means that more albatross taxa are now considered to be threatened (Croxall and Gales 1998). The great 
albatrosses Diomedea have been most affected by these taxonomic revisions, increasing from three species (Wandering D. exulans, Royal D. epomophora and Amsterdam Albatrosses D. amsterdamensis) to seven (with two species of Royal Albatross and four of Wandering Albatross). A phylogeny based on genetic evidence (complete cytochrome $b$ gene sequence, Nunn and Stanley 1998) suggests that Wandering Albatross sensu lato is polyphyletic, with Amsterdam Albatross a sister species to the widespread, southern exulans (sensu stricto). The two New Zealand forms D. [e.] gibsoni and D. [e.] antipodensis form another species pair, with Tristan Albatross D. [e.] dabbenena as the most distinct form.

Tristan Albatross, or Gony, is the most northerly-breeding form, restricted to Gough and Inaccessible Islands in the Tristan da Cunha group, central South Atlantic Ocean. It used to breed on the main island of Tristan, but was extirpated at the start of the twentieth century, primarily due to human exploitation (Fraser et al. 1988). The demipopulation at Inaccessible Island decreased from some 200 pairs in the 1870 s to no more than six pairs by the 1950s, probably due to predation by feral pigs as well as human exploitation (Fraser et al. 1988), remaining at 2 or 3 breeding pairs until at least 1990 (Ryan et al. 1990). Consequently the vast majority of Tristan Albatrosses are restricted to Gough Island, where the demipopulation was estimated to be roughly 2,000 pairs in the 1880 os (Verrill 1895) and again in 1955-1956 (Swales 1965). More accurate censuses of chicks during spring in the late 1970 s and early 1980s gave a maximum count of some 800 chicks (Watkins 1987), corresponding to a demipopulation of approximately 1,100 pairs (assuming breeding success of c. $70 \%$ to September-November; Williams and Imber 1982, this paper). This makes the Tristan Albatross the third rarest albatross species (Gales 1998). Although both Gough and Inaccessible Islands are protected as nature reserves, and the species is protected under the Tristan da Cunha Conservation Ordinance of 1976, at least some birds are known to have been killed as by-catch in longline fisheries (Cooper 1994). On the basis of inferred population declines linked to this mortality on longlines, Croxall and Gales (1998) recommended that the Tristan Albatross be listed as Endangered (criteria $\left.\mathrm{B}_{1}+\mathrm{B} 2 \mathrm{e}\right)$.

There have been no complete censuses of Tristan Albatross at Gough Island since 1982, and the population estimate for Gough has the lowest reliability rating for any great albatross population (Gales 1998). Here we report a complete census made in September 1999, and provide a protocol for future surveys. We also present counts for Inaccessible and Tristan, and summarize observations on breeding success, site fidelity, age at first reproduction and causes of mortality based on retraps and recoveries of banded birds at Gough Island over the past 20 years.

\section{Methods}

PGR and JPG counted all Tristan Albatross chicks at Gough Island from 14 to 16 September 1999. Albatross chicks at this time of year are highly visible as they are almost the size of adult birds but are still largely covered with white down and can be detected using binoculars from ranges of up to $1 \mathrm{~km}$. We counted chicks in all suitable breeding areas either by walking through the areas or (preferably) by scanning from one or more vantage points. Each river catchment 


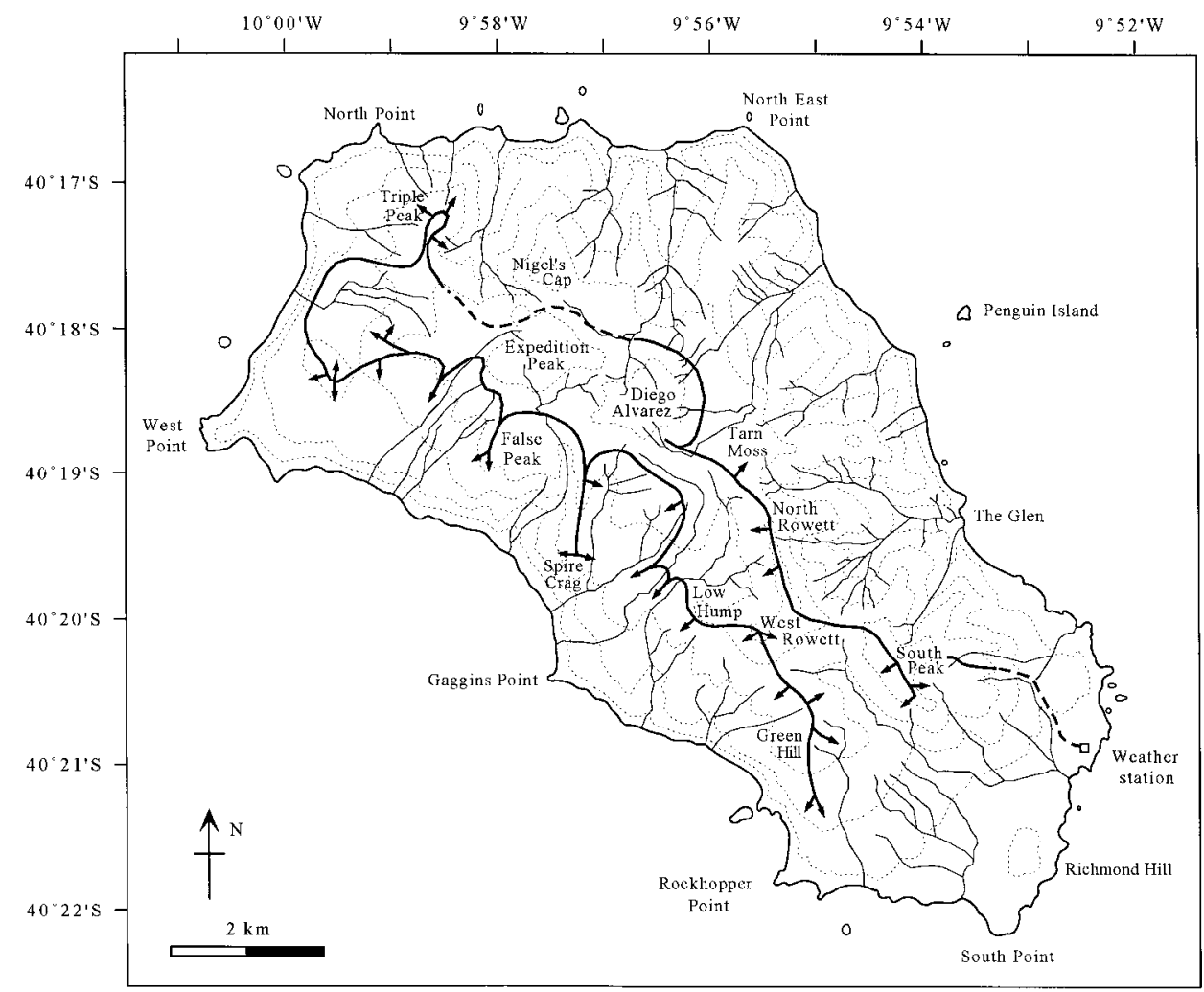

Figure 1. Gough Island, showing the census route and major vantage points (arrows). The dashed line around Expedition Peak completes the survey route through an area with no breeding Tristan Albatrosses.

was counted separately, using sketch maps to identify different tributaries so that repeat counts could detect additional birds obscured from previous vantage points. The count route (Figure 1) was loosely modelled on that reported by Williams and Imber (1982), and required 2-3 days of good visibility to complete. Use of a hand-held GPS proved a valuable safety tool in inclement weather; fixes of key scanning points are listed in Appendix 1. We assessed the efficiency of the count technique by comparing counts made using the scan technique with a count based on banding all chicks within a prescribed area. All chicks in the upper part of Gonydale were banded from 19 to 21 August 1999.

PGR visited Inaccessible Island from 4 November 1999 to 9 February 2000. Chicks from the 1999 breeding season were counted on 17 November 1999, and adults breeding in 2000 were counted on 4 February 2000. PGR was also based on Tristan for three weeks in October 1999 and again for 10 days in January 2000. During these visits, six day-trips to the Base were made to explore for Tristan Albatross from Round Hill in the south of the island clockwise to Morgie's Gulch in the north-east. The islanders were asked about sightings of Gonies on the island. 
Tristan Albatrosses were banded at Gough Island in 1955-1956 (200) and annually from 1976 to 1999 (average 81 birds per year, range 2-177). Regular banding of chicks in Gonydale commenced in 1980, and has been done in all but four years subsequently (missing 1981, 1993, 1995 and 1996). Chicks are generally banded during the spring relief voyage to the island (typically SeptemberNovember), but in some years they have been banded as early as mid-August. In three years the number of incubating adults in Gonydale was counted during January-February, enabling a crude estimate of breeding success (chicks banded/number incubating).

In 1989-1990 JC established a small study colony (7-22 pairs annually) around Tafelkop on the south-east slopes of South Peak. The latter site is the closest breeding locality to the meteorological station at Transvaal Bay. Volunteers among the station personnel staked out nests, banded adults and chicks and monitored breeding success, but coverage varied between years. Chicks surviving to spring (September-November) were banded in all years except 1997, but the number of eggs laid was not recorded in 1994 and 1996. A complete record of all partners was only obtained in a few years, confounding an accurate assessment of breeding frequency or mate fidelity. In some years there have also been checks for bands on incubating and brooding adults at Gonydale. The three main banding areas (Gonydale, Albatross Plain and Tafelkop) are separated by high peaks lacking any nests (Figure 2).

\section{Results}

\section{Population estimates}

At Gough Island, Tristan Albatrosses breed on gently sloping areas with short, wet heath vegetation, with a few nests extending downslope into the upper Blechnum palmiforme heath zone. Nests occur from $400 \mathrm{~m}$ (rarely $300 \mathrm{~m}$ ) to $700 \mathrm{~m}$ elevation, avoiding the exposed island peaks as well as denser fern bush and tussock vegetation at lower levels. Within this altitudinal range, they occur primarily on the upper parts of the western, convex slopes of the island, and are absent from the steep-sided glens that characterize the eastern and northern sides of the island (Figure 2). Where they occur on slopes, there is a marked preference for north- and west-facing slopes. They avoid peat bogs, which are presumably too wet for nesting. Breeding is loosely colonial, but some pairs nest up to 500 $\mathrm{m}$ away from other nests. Minimum inter-nest distance may be as little as $3 \mathrm{~m}$, although this is hard to tell in spring as chicks start to move around, often building several play nests.

We counted 1,129 chicks in mid-September 1999, over 300 more than the previous highest chick count (798 in October 1982, Watkins 1987). The $38 \%$ increase relative to 1982 was primarily due to increases in three areas: Gonydale/Green Hill, Spire Crag and False Peak (Table 1). Routes taken by previous surveys apparently did not venture far from the spine of the island in these areas (cf. Williams and Imber 1982) and presumably failed to count some chicks. Scan counts proved to be at least as accurate as banding chicks. We counted 73 chicks in three well-defined sectors of Gonydale where four weeks previously 70 had been banded and two others left unbanded. 


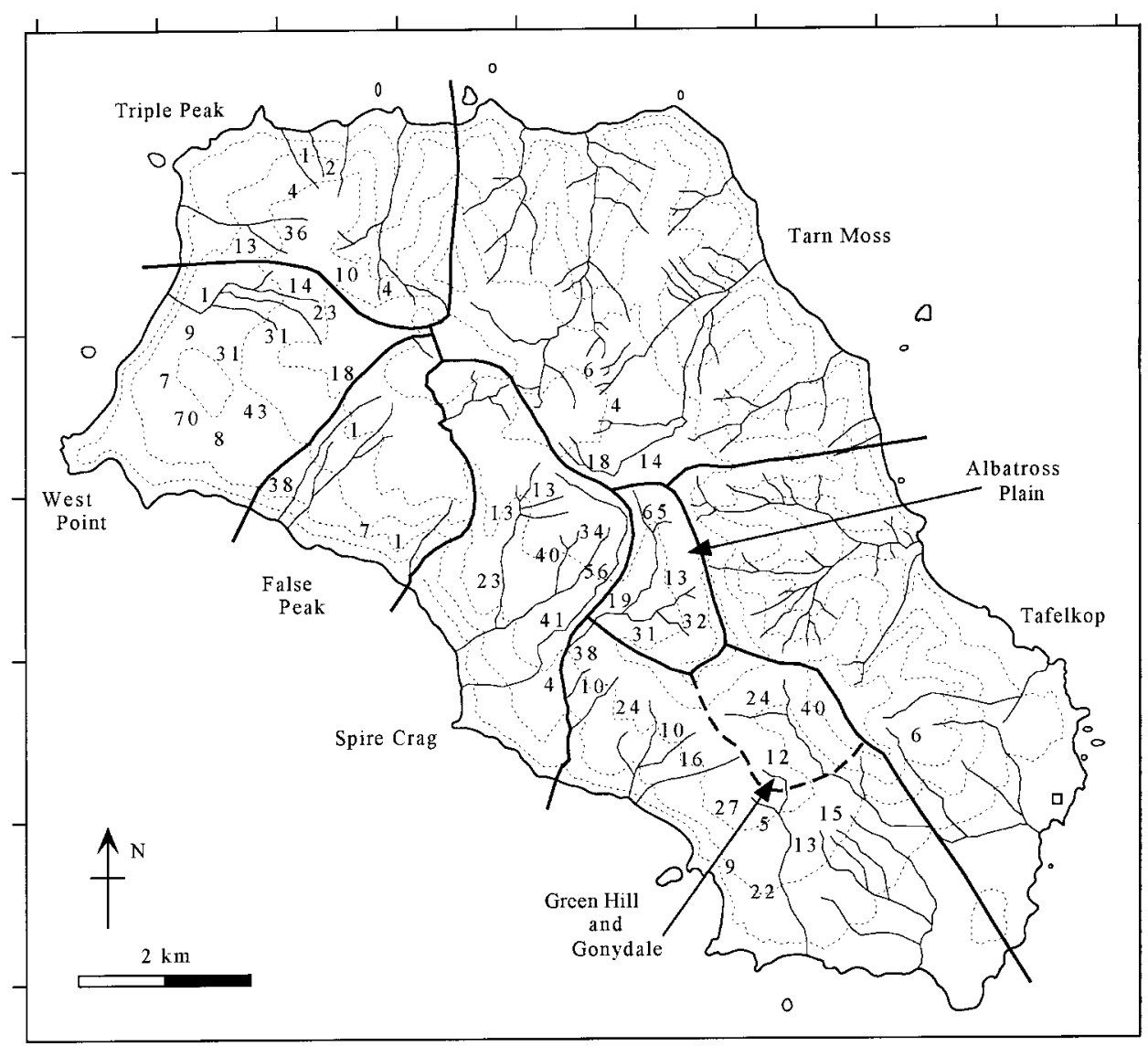

Figure 2. The distribution of Tristan Albatrosses at Gough Island and the boundaries of census areas. Figures are numbers of chicks counted.

Table 1. Counts of Tristan Albatross breeding in different sectors of Gough Island (see Figure 2 for sector boundaries)

\begin{tabular}{lcccc}
\hline Area & $\begin{array}{l}1956^{a} \\
\text { (adults) }\end{array}$ & $\begin{array}{l}1982^{b} \\
\text { (chicks) }\end{array}$ & $\begin{array}{l}\text { 1999 } \\
\text { (chicks) }\end{array}$ & $\begin{array}{c}\text { \% change } \\
1999 \text { vs 1982 }\end{array}$ \\
\hline A Tafelkop & 0 & 13 & 6 & -54 \\
B Green Hill and Gonydale & 700 & 84 & 265 & +215 \\
C Albatross Plain & 430 & 168 & 160 & -5 \\
D Spire Crag & 35 & 113 & 224 & +98 \\
E False Peak & 10 & 55 & 107 & +95 \\
F West Point & 35 & 260 & 255 & -2 \\
G Triple Peak & 16 & 68 & 70 & +3 \\
H Tarn Moss & 0 & 37 & 42 & +14 \\
Total & 1,226 & 798 & 1,129 & +41 \\
\hline
\end{tabular}

${ }^{a}$ After Swales 1965 .

${ }^{b}$ Percy FitzPatrick Institute unpubl. data; for summary see Watkins 1987. 
Table 2. Numbers of Tristan Albatross banded in different areas of Gough Island

\begin{tabular}{lcrr}
\hline Locality & Adults & Chicks & Total \\
\hline Tafelkop & 102 & 114 & 216 \\
Gonydale & 233 & 1,101 & 1,334 \\
Albatross Plain & 141 & 105 & 246 \\
Tarn Moss & 1 & 1 & 2 \\
Sea Hen Crag (near Triple Peak) & 0 & 50 & 50 \\
West Point & 0 & 20 & 20 \\
Locality uncertain & 203 & 79 & 282 \\
Total & 680 & 1,470 & 2,150 \\
\hline
\end{tabular}

At Inaccessible Island, one chick fledged from the 1999 season, and a second pair were incubating an egg in February 200o. All breeding activity took place on Gony Ridge near the western summit of the island, in short vegetation dominated by stunted bogferns Blechnum palmiforme and grasses such as Calamagrostis deschampsiiformis and Agrostis holdgateana. The former nest was near the western end of Gony Ridge $\left(37^{\circ} 18.4^{\prime} \mathrm{S}, 12^{\circ} 41.8^{\prime} \mathrm{W}\right)$ whereas the 2000 nest was towards the eastern end $\left(37^{\circ} 18.3^{\prime} \mathrm{S}, 12^{\circ} 41.4^{\prime} \mathrm{W}\right)$. Two other adults were apparently loafing near the active nest at the east end of Gony Ridge in February 2000. The fledgling from the 1999 season and three adults were banded.

At least two Tristan Albatross were observed flying over the Base at Tristan: one adult from Hottentot Gulch west over Nellie Hump on 14 October, and a subadult (brown back and heavy breast band) south over the Knobs above Burntwood. Four hours later what was presumably the same bird was seen circling low over Green Hill on 12 February. None were seen on the ground, but they tend to breed in hollows and can be overlooked. However, it is unlikely that any currently breed in the western half of the island between Gypsy's Gulch in the south and Morgie's Gulch in the north-east as this area is fairly regularly visited by islanders who graze sheep here. Few islanders venture outside this area, and therefore some Gonies could breed in the south-eastern sector of the island, not visited during 1999-2000. In the 1960s at least one pair was reported to breed on the eastern slope of Round Hill, in the south of the island (Lindsay Repetto pers. comm.), when the island's human population returned after being evacuated to the U.K. following the volcanic eruption in 1961.

\section{Causes of mortality}

A total of 2,150 Tristan Albatross has been banded at Gough Island. Most $(68.3 \%)$ were banded as chicks. Banding effort has been greatest in the south of the island, with more than 1,300 birds banded at Gonydale and more than 200 at Albatross Plain and Tafelkop (Table 2). Only seven banded birds have been recovered dead at Gough Island. Skeletal remains of four birds banded as chicks were found within a year of banding, presumably having failed to fledge. The other three were breeding adults. One was banded as a non-breeding bird in the Tafelkop study colony in 1992, bred in the colony in 1994, 1996 and 1998, and was found dead next to its nest on 30 April 1998. The cause of death was not apparent. The other two adults were both killed when their nests were engulfed 


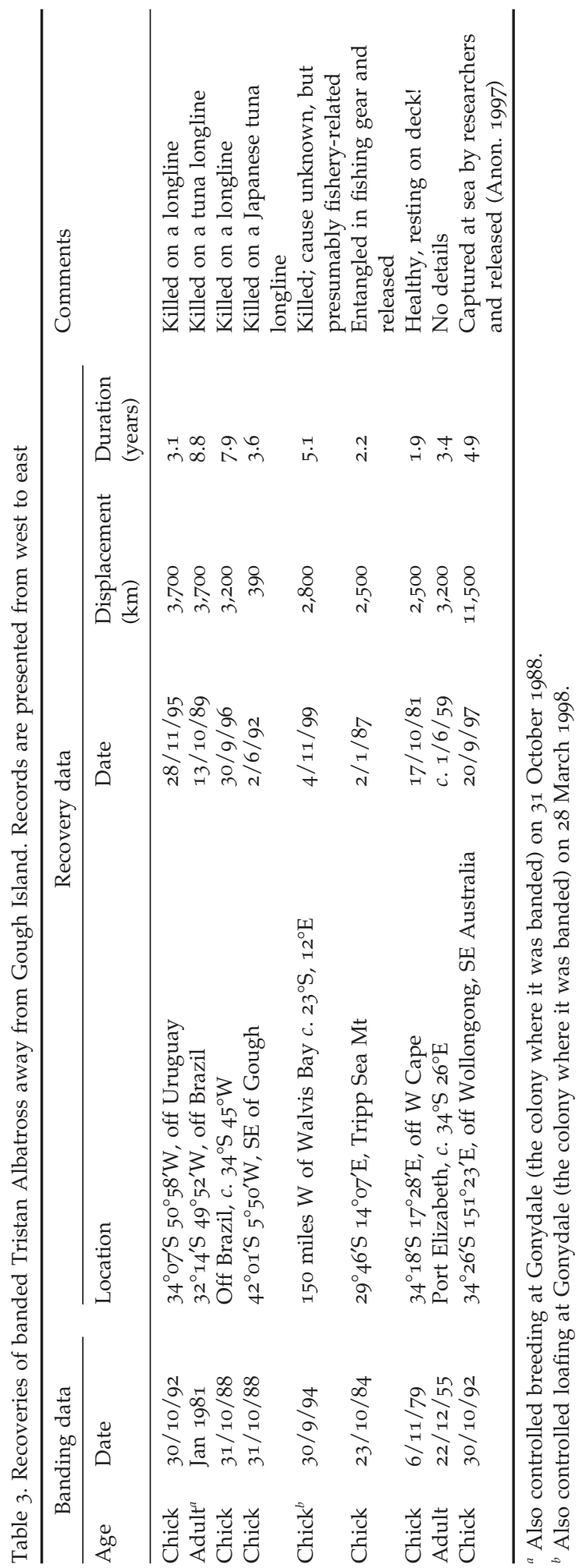


by peatslips caused by intense rainfall in March 1999. A third nest was entirely buried by these peatslips, almost certainly killing the bird that was brooding its small chick at the time. This single event destroyed 3 of 14 nests in the Tafelkop study colony.

The nine recoveries of banded Tristan Albatrosses away from Gough Island have all been at sea, with the possible exception of one bird recovered at Port Elizabeth for which there are no recovery details (Table 3). Seven were banded as chicks, but this is not significantly different from the proportion expected by chance, given the greater proportion of chicks banded overall. At least four birds were killed on longlines, and another was released after being entangled in fishing gear. Most of the birds affected by fisheries were relatively young. Of the birds banded as chicks, birds killed on longlines were four, five and eight years old. The bird released after being entangled in fishing gear was three years old, and the other recoveries at sea lacking adequate information involved birds aged two and six years. Only one fully adult bird (banded as an adult, and recovered eight years later) was killed on a longline (Table 3).

\section{Breeding biology}

Although there have been relatively few recoveries of dead birds, 227 banded birds have been controlled alive at Gough Island, with a total of 378 resightings (maximum of seven controls for one bird). Birds banded as adults ( 118 individuals controlled; $17.4 \%$ of adults banded) were much more likely to be resighted than birds banded as chicks (109 controls; $7.4 \%, \chi^{2}=47.6, P<0.001$ ). There have been no further sightings or recoveries of the 200 birds banded in 1955-1956 beyond that reported by Cooper (1983). The longevity record is just over 22 years between banding (as an adult on 22 December 1955) and resighting (breeding adult on 24 March 1978). Among recently banded birds, one banded as an adult on 20 May 1979 was still breeding at the same colony on 29 March 1998, almost 19 years later.

Young birds first returned to the island 3-4 years after being banded as chicks (i.e. $4-5$ years old), and some birds started breeding at six years $(n=3)$. Estimating the average age of first breeding is complicated by the inconsistent search effort and the relatively small number of chicks banded prior to 1988 (thus giving enough time for the cohort to recruit fully, cf. Croxall et al. 1990). Figure 3 shows the ages of recruits at Tafelkop, where search effort was more consistent. The modal age of first breeding was eight years. The maximum age of first breeding was 18 years at Tafelkop (19 years at Gonydale), close to the maximum period birds have been banded at these colonies, suggesting that breeding attempts were overlooked at both colonies, and thus biasing any estimate of average age of first breeding.

Most birds banded as chicks returned to their natal colony to breed $(81 \%, n=$ 69). All 13 birds breeding away from their natal colony were found at Tafelkop; 12 were from Gonydale (c. I km away) and I from Albatross Plain (c. $3 \mathrm{~km}$ away). None of the 70 birds banded as chicks in the northern part of the island has been resighted in the south of the island. Of pre-breeding birds observed loafing, $89 \%$ were in their natal colony $(n=38)$. Adults showed greater fidelity 


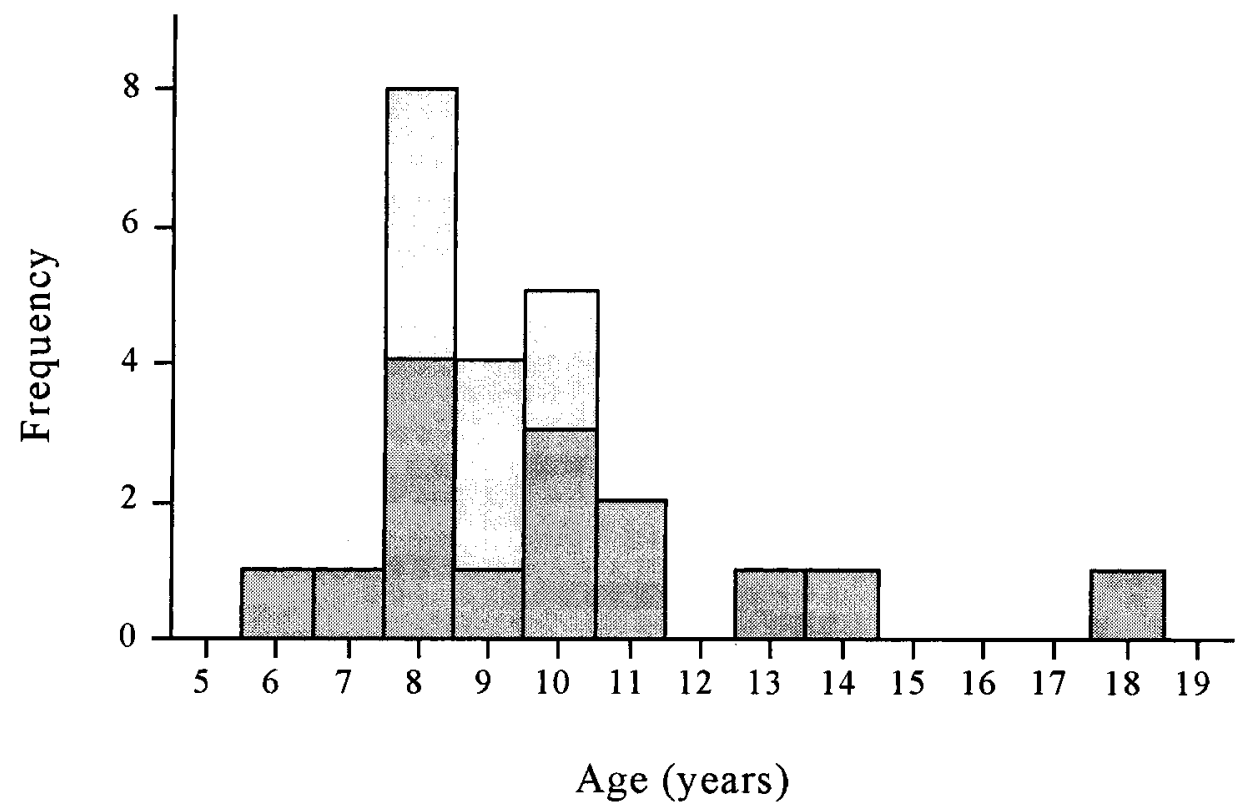

Figure 3. Age of first reproduction of Tristan Albatrosses breeding at Tafelkop. Dark shading is birds banded as chicks prior to 1988; light shading is birds banded from 1988 to 1992.

to breeding site (97\%, $n=125$ individuals). Only four birds definitely bred at more than one colony: two adults from Tafelkop and one from Albatross Plain were later found breeding at Gonydale, and one from Gonydale subsequently bred at Tafelkop. Four other birds banded as adults have also been seen at two colonies, but were loafing at one site.

Both individuals of 38 pairs breeding at Tafelkop were banded. Mate fidelity among pairs that bred more than once was high ( $94 \%, n=53$ breeding attempts). Birds apparently switched mates on three occasions. Crude breeding success (numbers of chicks fledged/eggs laid) averaged $46 \%$ (range $25-72 \%, n=8$ years) at Tafelkop compared with $69 \%$ (range $58-76 \%, n=3$ years) at Gonydale. Combining all years from both colonies gives an average success of $63 \%$ ( $n=400$ nests). Numbers of chicks fledged were more variable at Tafelkop (mean 7.0 \pm 3.1, range $2-13$ chicks, CV 46\%, $n=12)$ than at Gonydale $(67.1 \pm 9.3,53-84, \mathrm{CV}$ $17 \%, n=16$ ). This excludes 1991, when 95 chicks were banded in Gonydale, but included birds from outside the normal study area. There was no significant trend in chick production at Gonydale during 1979-1999 $\left(r_{17}=0.297, P>0.2\right)$. During the 10-year study period at Tafelkop, no bird that raised a chick attempted to breed the following year. One pair raised five chicks (and failed once), two pairs raised three chicks, and 14 pairs raised at least two chicks. At least two pairs had $\geqslant_{4}$ breeding failures during the same period. Incomplete records in some years prevent a more detailed analysis of each pair's productivity and frequency of reproduction. 


\section{Discussion}

The breeding biology of Tristan Albatross is similar in broad detail to that reported for the much better-studied nominate Wandering Albatross Diomedea [e.] exulans (e.g. Tickell 1968, Weimerskirch and Jouventin 1987, Croxall et al. 1990). The only difference is perhaps to breed at a slightly younger age than Wandering Albatrosses at Bird Island, South Georgia (modal age 10-11 years, Croxall et al. 1990) or at Possession Island in the Crozets (modal age 9-10 years, Weimerskirch et al. 1997). This is despite a decrease in the average age of first breeding in these populations in the past 20 years. Unfortunately there are no comparative data for the other, more northerly breeding taxa D. amsterdamensis, D. [e.] antipodensis or D. [e.] gibsoni (cf. Weimerskirch et al. 1997, Walker and Elliott 1999). The slightly younger recruitment age does not fully account for the darker, more juvenile plumage of breeding Tristan Albatrosses. Birds of known age and sex at Gough Island were significantly darker than comparable D. [e.] exulans breeding at Marion Island (Ryan 2000).

Despite the known mortality on longlines, there is no evidence of a decrease in the breeding population of Tristan Albatross. There is no significant trend in the number of chicks banded at Gonydale during 1979-1999, but the regression slope is positive, suggesting that if anything numbers have increased. The larger number of chicks counted in 1999 relative to counts between 1979 and 1982 could be due to (1) a population increase, (2) a relatively poor breeding season in 1998, resulting in more pairs than usual returning to breed the following year, (3) greater coverage in 1999, or a combination of all three. Breeding success in 1998 was below average in Gonydale (58\%) and Tafelkop (36\%), but the fact that the increase was concentrated in three count sectors, while other count sectors remained almost identical to the peak count of 1982, suggests that greater coverage of these sectors played a significant role in 1999. The count in 1999 took place earlier in the year than in 1982, probably resulting in lower values for chick mortality in 1999. However, observations and band recoveries indicate that very few chicks die towards the end of the nestling period.

Assuming a breeding success of around $70 \%$ to September (Williams and Imber 1982, this paper), the 1992 chick count represents an annual breeding effort of some 1,500 pairs. Like other great albatrosses (Diomedea, sensu stricto, Nunn et al. 1994), Tristan Albatross raise at most one chick every two years, but may attempt to breed the year following a failure (Tickell 1968, Croxall et al. 1990). In a stable population of Wandering Albatrosses, the demipopulation breeding in an average year represents roughly $59 \%$ of the total breeding population. The number of independent juveniles and immatures is about $82 \%$ of the total breeding population (Weimerskirch et al. 1997). This suggests that the total breeding population of Tristan Albatross is approximately 2,500 pairs (5,000 birds) with a total population of 9,000 individuals. These values are likely to be optimistic, however, given that there was below average breeding success in 1998, and thus a larger number of birds would be expected to breed in 1999. Repeated censuses in successive years are required to resolve this problem.

The 1999 estimate of 1,500 pairs is greater than the demipopulation reported by Swales's (1965) map (1,226 pairs estimated during incubation, M.K. Swales in litt.; Table 1). However, the most surprising result is the marked difference in 
the distribution of breeding from Swales's map and more recent counts. Swales's map shows 92\% of birds breeding in Albatross Plain and Gonydale/Green Hill, compared with only $32 \%$ in 1982 and $38 \%$ in 1999 (Table 1 ). The counts from the late 1970 and early 1980 s show a similar distribution to that observed in 1999 . Given the strong fidelity to natal and breeding sites, it seems unlikely that more than half the population moved to the north of the island between 1955 and 1979. Michael Swales (in litt.) is confident that the northern areas were explored thoroughly and there were few birds there in 1955-1956; he could shed no light on this mystery.

Although peatslips are an unusual but potentially significant source of adult mortality on the steeper slopes of Gough Island, with sporadic extreme rainfall events occurring chiefly in autumn (Ryan 1993) when adults are brooding chicks, the most important mortality probably results from longline fishing. In addition to the evidence from band recoveries, longline fisheries off the east coast of South America are estimated to kill some 30 Tristan Albatrosses each year (Neves et al. 2000, Olmos et al. 2000). These fisheries have some of the highest seabird by-catch rates. Also, Nick du Plessis, Captain of the Kelso, reported 10 Gonies floating dead off Gough in February 2000. At the time Spanish conversations were heard on short-range (VHF) radio channels, suggesting that longline vessels were fishing illegally inside the island's Exclusive Economic Zone, presumably over McNish Seamount. The apparent stability of the Tristan Albatross population could be misleading; demographic models indicate that the breeding population can remain stable for up to 10 years after the total population starts to decrease (Moloney et al. 1994).

Knowledge of a seabird's foraging range can help identify areas of overlap with longline fisheries. The recoveries of banded birds away from Gough Island suggest that Tristan Albatrosses range throughout the temperate South Atlantic (at least $23^{\circ}-42^{\circ} \mathrm{S}$ ), extending into the south-western Indian Ocean. Despite the recovery of a banded bird off south-east Australia, it is unlikely that they routinely visit these waters, because none of the many great albatrosses banded at sea off south-east Australia has been found at Gough Island. By comparison, numerous Australian-banded birds have been found at Marion Island (FitzPatrick Institute, unpubl. data) and at New Zealand breeding colonies $(\mathrm{H}$. Battam in litt.). More detailed information on foraging range is a priority.

The status of Tristan Albatross at the main island of Tristan warrants further investigation. Reports of a nest at Tristan in the 1960s were repeated by several islanders, but this is not mentioned by Richardson (1984). Elliott (1957) reported increasing numbers of birds flying over the island in the 1950s, similar to our 1999-2000 observations, but Richardson saw none during 1972-1974 (Richardson 1984). Given that we observed Gonies flying over the plateau at Inaccessible on only three occasions in more than a month on the plateau, the sightings of two birds over the Base at Tristan in a mere six day-visits suggests that they are certainly interested in breeding at the island, if not yet actually doing so. It may be that a small number already breed in the area not explored. There is certainly plenty of suitable habitat, and if breeding has not already commenced, it could be promoted by placing models of albatrosses at suitable sites such as the periphery of Soggy Plain behind Round Hill $\left(37^{\circ} 08.5^{\prime} \mathrm{S}, 12^{\circ} 17 \cdot 7^{\prime} \mathrm{E}\right)$. The small population of Tristan Albatross on Inaccessible Island has remained constant for more 
than 50 years, which appears strange given the apparent exploration of Tristan as a potential breeding site. One factor could be limited suitable habitat (Ryan et al. 1990).

To conclude, there is no evidence that the population of Tristan Albatross has declined dramatically since the early 1980 os despite mortality on longlines since at least 1989. With a total population of less than 10,000 birds, however, effectively restricted to one breeding site, it qualifies as Vulnerable (criterion D2). Regular surveys are required to monitor the status of this species, and active steps should be taken to promote recolonization of Tristan.

\section{Acknowledgements}

We thank volunteers from Gough teams who have monitored Tristan Albatross breeding success: P. Cronje, B. and D. Enslin, P. Greyling, S. Lategan, B. Lawson, A. Lombard, R. Mathews, G. Roberts, A. Smit, C. Smorenburg, B. Stead, W. Stranix, P. van der Waal, G. van Eeden and S. Worth. We are especially grateful to Belinda and Didi Enslin for their observations, and for banding the chicks in Gonydale in 1999. Coleen Moloney assisted with surveys at Inaccessible and Tristan. Banding records were administered efficiently by SAFRING. PGR visited Gough Island during 1999 as Environmental Inspector for the Tristan Government. Funding was received from the World Wide Fund for Nature (U.K.), with logistical support from the South African Department of Environmental Affairs and Tourism: Directorate Antarctica and Islands and Tristan's Natural Resources Department.

Appendix 1. Coordinates of key points on the census route at Gough Island

\begin{tabular}{lll}
\hline Location & Census area $^{a}$ & Coordinates $^{\prime}$ \\
\hline Tafelkop & 1 & $40^{\circ} 20.3^{\prime} \mathrm{S} 9^{\circ} 53 \cdot 7^{\prime} \mathrm{W}$ \\
South Peak & 2 & $40^{\circ} 20.3^{\prime} \mathrm{S} 9^{\circ} 54 \cdot 5^{\prime} \mathrm{W}$ \\
Mt Zeus & 2 & $40^{\circ} 20.5^{\prime} \mathrm{S} 9^{\circ} 54 \cdot 4^{\prime} \mathrm{W}$ \\
West Rowett & 2 & $40^{\circ} 20.1^{\prime} \mathrm{S} 9^{\circ} 55.8^{\prime} \mathrm{W}$ \\
Green Hill (peak) & 2 & $40^{\circ} 20.7^{\prime} \mathrm{S} 9^{\circ} 55 \cdot 5^{\prime} \mathrm{W}$ \\
South end of Green Hill ridge & 2 & $40^{\circ} 21.0^{\prime} \mathrm{S} 9^{\circ} 55 \cdot 3^{\prime} \mathrm{W}$ \\
West ridge of Low Hump & 2 & $40^{\circ} 20.0^{\prime} \mathrm{S} 9^{\circ} 56.6^{\prime} \mathrm{W}$ \\
Centre Rowett & 3 & $40^{\circ} 19.8^{\prime} \mathrm{S} 9^{\circ} 55 \cdot 6^{\prime} \mathrm{W}$ \\
North Rowett & 3 & $40^{\circ} 19 \cdot 4^{\prime} \mathrm{S} 9^{\circ} 55.8^{\prime} \mathrm{W}$ \\
East end of Albatross Plain ridge & 4 & $40^{\circ} 19.1^{\prime} \mathrm{S} 9^{\circ} 56.4^{\prime} \mathrm{W}$ \\
Spire Crag & $4 / 5$ & $40^{\circ} 19.6^{\prime} \mathrm{S} 9^{\circ} 57.6^{\prime} \mathrm{W}$ \\
West spur of False Peak & 5 & $40^{\circ} 18.9^{\prime} \mathrm{S} 9^{\circ} 58.5^{\prime} \mathrm{W}$ \\
West Point hump & 6 & $40^{\circ} 18.3^{\prime} \mathrm{S} 9^{\circ} 59.8^{\prime} \mathrm{W}$ \\
North end of Long Hump (Battle Bay) & 6 & $40^{\circ} 17.6^{\prime} \mathrm{S} 9^{\circ} 59 \cdot 7^{\prime} \mathrm{W}$ \\
Triple Peak (north-western peak) & 7 & $40^{\circ} 17.2^{\prime} \mathrm{S} 9^{\circ} 58.9^{\prime} \mathrm{W}$ \\
\hline
\end{tabular}

See Table 1.

\section{References}

Anon. (1997) Gough Island Albatross: a first for Australia. Albatross (Southern Oceans Seabird Study Association newsletter) 16: 5.

Bourne, W. R. P. and Warham, J. (1999) Albatross taxonomy. Birding World 12: 123-124. Cooper, J. (1983) Bird ringing at Gough Island, 1977-1982. S. Afr. J. Antarct. Res. 13: 47-48. 
Cooper, J. (1994) Seabird mortality from longline fisheries: evidence from Marion and Gough Islands. CCAMLR-WG-IMALF-94/18.

Croxall, J. P. and Gales, R. (1998) An assessment of the conservation status of albatrosses. Pp. 46-65 in G. Robertson and R. Gales, eds. Albatross biology and conservation. Chipping Norton, NSW: Surrey Beatty.

Croxall, J. P., Rothery, P., Pickering, S. P. C. and Prince, P. A. (1990) Reproductive performance, recruitment and survival of Wandering Albatrosses Diomedea exulans at Bird Island, South Georgia. J. Anim. Ecol. 59: 775-796.

Elliott, H. F. I. (1957) A contribution to the ornithology of the Tristan da Cunha group. Ibis 99: $545-586$.

Fraser, M. W., Ryan, P. G. and Watkins, B. P. (1988) The seabirds of Inaccessible Island, South Atlantic Ocean. Cormorant 16: 7-33.

Gales, R. (1998) Albatross populations: status and threats. Pp. 20-45 in G. Robertson and R. Gales, eds. Albatross biology and conservation. Chipping Norton, NSW: Surrey Beatty.

Moloney, C. L., Cooper, J., Ryan, P. G. and Siegfried, W. R. (1994) Use of a population model to assess the impact of longline fishing on Wandering Albatross Diomedea exulans populations. Biol. Conserv. 70: 195-204.

Neves, T., Vooren, C. M. and Bastos, G. (2000) Proportions of Tristan and Wandering Albatrosses in incidental captures off the Brazilian coast. Second International Conference on the Biology and Conservation of Albatrosses and Other Petrels, Honolulu. (abstract, p. 44).

Nunn, G. B. and Stanley, S. E. (1998) Body size effects and rates of cytochrome $b$ evolution in tube-nosed seabirds. Mol. Biol. Evol. 15: 1360-1371.

Nunn, G. B., Cooper, J., Jouventin, P., Robertson, C. J. R. and Robertson, G. G. (1994) Evolutionary relationships among extant albatrosses (Procellariiformes: Diomedeidae) established from complete cytochrome $b$ gene sequences. Auk 113: 784-801.

Olmos, F., Bastos, G. C. C. and Neves, T.d S. (2000) Estimating seabird bycatch in Brazil. Second International Conference on the Biology and Conservation of Albatrosses and Other Petrels, Honolulu. (abstract, p. 48).

Richardson, M. E. (1984) Aspects of the ornithology of the Tristan da Cunha group and Gough Island, 1972-1974. Cormorant 12: 123-201.

Robertson, C. J. R. and Nunn, G. B. (1998) Towards a new taxonomy for albatrosses. Pp. 13-19 in G. Robertson and R. Gales, eds. Albatross biology and conservation. Chipping Norton, NSW: Surrey Beatty.

Ryan, P. G. (1993) The ecological consequences of an exceptional rainfall event at Gough Island. S. Afr. J. Sci. 89: 309-311.

Ryan, P. G. (2000) Tristan or Wandering Albatross? Africa: Birds and Birding 5: 35-39.

Ryan, P. G., Dean, W. R. J., Moloney, C. L., Watkins, B. P. and Milton, S. J. (1990) New information on seabirds at Inaccessible Island and other islands in the Tristan da Cunha group. Mar. Orn. 18: 43-54.

Swales, M. K. (1965) The sea-birds of Gough Island. Ibis 107: 17-42, 215-229.

Tickell, W. L. N. (1968) The biology of the great albatrosses, Diomedea exulans and Diomedea epomophora. Antarct. Res. Ser. 12: 1-55.

Verrill, G. E. (1895) On some birds and eggs collected by Mr. G. Comer at Gough Island, Kerguelen Island and South Georgia and extracts from his notes. Trans. Connect. Acad. 9: $430-478$.

Walker, K. and Elliott, G. (1999) Population changes and biology of the Wandering Albatross Diomedea exulans gibsoni at the Auckland Islands. Emu 99: 239-247.

Watkins, B. P. (1987) Population sizes of King, Rockhopper and Macaroni Penguins and Wandering Albatrosses at the Prince Edward Islands and Gough Island, 1951-1986. S. Afr. J. Antarct. Res. 17: 155-162. 
Weimerskirch, H. and Jouventin, P. (1987) Population dynamics of the Wandering Albatross, Diomedea exulans, of the Crozet Islands: causes and consequences of their population decline. Oikos 49: 315-322.

Weimerskirch, H., Brothers, N. and Jouventin, P. (1997) Population dynamics of Wandering Albatross Diomedea exulans and Amsterdam Albatross D. amsterdamensis in the Indian Ocean and their relationships with long-line fisheries: conservation implications. Biol. Conserv. 79: 257-270.

Williams, A. J. and Imber, M. J. (1982) Ornithological observations at Gough Island in 1979, 1980 and 1981. S. Afr. J. Antarct. Res. 12: 40-45.

PETER G. RYAN

Percy FitzPatrick Institute, University of Cape Town, Rondebosch 7701, South Africa. E-mail: pryan@botzoo.uct.ac.za

JOHN COOPER

Avian Demography Unit, University of Cape Town, Rondebosch 7701, South Africa.

JAMES P. GLASS

Natural Resources Department, Tristan da Cunha, South Atlantic (via Cape Town). 